Nabila Puspa Adiyanti

Department of Public Administration, Faculty of Administrative Science, University of Indonesia

(email: bellapuspa21@gmail.com)

\title{
Reza Fathurrahman
}

Department of Public Administration, Faculty of Administrative Science, University of Indonesia

(email: rezafathurrahman@ui.ac.id)

Submitted: 16 October 2020, Revised: 23 March 2021, Accepted: 23 March 2021

\begin{abstract}
Adiyanti, Nabila Puspa is a Junior Researcher at Research Cluster Policy, Governance, and Administrative Reforms (PGAR) - FIA UI, chaired by Professor Eko Prasojo. She was born in Jakarta, March $21^{\text {st }} 1998$. She obtained her bachelor's degree in the Department of Public Administration - Faculty of Administrative Science at Universitas Indonesia in 2020. Her research interest includes New Public Management paradigm, Government Infrastructure Development, Comparative Public Administration, Institutional Reform, and Civil Service Reform.
\end{abstract}

\section{Fathurrahman, Reza is an} Assistant Professor in the field of Public Administration. Currently, he serves as the Secretary of Postgraduate School and as the Head of International Office, Faculty of Administrative Science, Universitas Indonesia. He pursued his bachelor's degree in Psychology from Universitas Padjadjaran. Afterward, he obtained his master's degree in public policy from the Willy Brandt School of Public Policy, University of Erfurt, and received his doctorate from the Leibniz University of Hannover, both with a full scholarship from DAAD (German Academic Exchange Service). As an active member of the Policy, Governance, and Administrative Reform (PGAR) Research Cluster at the Faculty, his research interests include administrative reform, organizational culture, and change management issues.

Policy \& Governance Review ISSN 2580-4820

Vol. 5, Issue 2, pp. 164-181

DOI: https://doi.org/10.30589/pgr. v5i2.348

\section{Assessing Critical Success Factors for PPP Water Project in Indonesia: Lessons from West Semarang}

\begin{abstract}
A very low success rate of PPP infrastructure projects between 2005 and 2015 has encouraged the Indonesian government to adopt the BOT scheme as the main strategy to accelerate the progress. Although the National Government has attempted to amend the presidential regulations three times in a row, only one out of seven priority national water supply projects reached a financial close and started the project. Using Ameyaw and Chan's theoretical framework (2016), this article examines the case of West Semarang as a leading example to improve understanding of the key success factors for successful PPP implementation in Indonesia's drinking water supply sector. Multiperspective data, incorporating views of national and local actors and relevant government documents, were analyzed for the purpose of this study. The findings highlight five critical success factors: Strong commitment from the contracting agency, as well as local and national government, experienced project partners, long-term capital, tangible political support, and the existence of Indonesia PPP Joint Office. Finally, recommendations to improve PPP implementation in drinking-water projects are suggested accordingly.
\end{abstract}

\section{Keywords:}

success factors; public-private partnership; water supply project; developing countries

\section{Introduction}

Development is a process of making change undertaken by some planned efforts (Riyadi \& Baratakusumah, 2005). Initially, the concept of development was used in the sense of growth. The state is considered successful in development if the country's economic growth is high enough.
Successful development is measured by state productivity or community productivity (Harun \& Ardianto, 2011). Infrastructure is needed to improve the productivity of the states. If there is no infrastructure available, production activities in various economic sectors cannot function. That being said, 
infrastructure is one of the most important factors of development (Todaro \& Smith, 2012).

Infrastructure development is a main concern for many countries. It is a general belief that improving infrastructure will implicate economic growth. A country's economic growth cannot be separated from infrastructure provisions such as drinking water supply, sanitation, telecommunications, transportation, and energy (Carnis \& Yuliawati, 2013). Infrastructure development was usually budgeted through a loan, which rise a country's level of debt. In the 1970 s to 1980 s, there was an escalation in state debt for infrastructure development, leading to economic instability. The governments started to encourage private sectors to invest in infrastructure to reduce government spending on infrastructure development. The involvement of the private sector in public services, specifically infrastructure provision, is a new concept of the public administration paradigm, namely New Public Management (NPM) (Rakić \& Rađenović, 2011).

Public Private Partnership (PPP) is one of NPM paradigm tools. Firstly introduced around the 1980s, it represents a collaboration between the public sector and the private sector to provide public service with a fair risk allocation in achieving the desired results of public service (Rakić \& Rađenović, 2011). Walker and colleagues (1995, as cited in Cheung, Chan, \& Kajewski, 2009) contend that there are three main reasons for applying for the PPP scheme: The primary reason is that the government wants to get a largescale source of funding to finance infrastructure projects. The second reason relates to the assumption that the private sector has a better capacity to provide public services. Finally, the third rationale for PPP is that the private sector has higher mobility than the government.

PPP in Indonesia is known as Kerjasama Pemerintah dan Badan Usaha (KPBU). PPP implementation in Indonesia was started for the first time during the economic crisis in 1997-1998 in Southeast Asia, which affected infrastructure financing in Indonesia. The financial crisis in Indonesia made the government reduce spending on development because the government needs to fix more important problems at that time, such as currency devaluation, capital flights by private parties, unstable political conditions, and social problems (The World Bank, 2004, p. 1). As a consequence, the spending decreased on development was leading to a decrease in Indonesia's infrastructure quality.

Indonesia started to implement PPP in 1998 through the issuance of a Presidential Decree No. 7/1998 on Cooperation of GovernmentPrivate Business Entities in the Development and Management of Infrastructure. However, this Decree was considered as the government's reluctance to relinquish direct control and to introduce a selection system for determining the most reliable private investor through a competitive tendering process. This circumstance made the potential investors decide to abandon their intention because Presidential Decree No. 7/1998 was considered problematic. The main problem within this regulation is the unfair risk allocation that private investors have to be borne (The World Bank, 2004, p. 58). Furthermore, the World Bank also argues that Indonesia's economic crisis was worsened by political instability, reduced budget allocations for infrastructure, its reputation for red tape bureaucracy, a weak judicial system, and rampant corruption. All of these factors complicated the struggles for private parties who want to invest in infrastructure development.

In 2005, modification of the pre-existing law had raised new hope for PPP implementation in Indonesia. There was an amendment from Presidential Decree No. 7/1998 to Presidential Regulation No. 67/2005 (Susantono \& Berawi, 2012). The government held Indonesia Infrastructure Summit in 2005 to promote PPP 
implementation by offering 91 infrastructure projects to the investors (Adji, 2010, p. 27). Yet this attempt failed to achieve its primary objective since the investors still did not know how the PPP project worked. Out of 91 projects, there were only six bidders, and just one project started the construction stage (Wibowo, 2006).

For the second time in a row, the government amended Presidential Regulation No. 67/2005 to Presidential Regulation No.13/2010 on PPP in Provision of Infrastructure (Adji, 2010). In addition, the government, through National Development Agency/Badan Perencanaan Pembangunan Nasional (Bappenas), launched Indonesia PPP Book 2010-2014, which offered 100 infrastructure projects to the investors. Those projects consist of various sectors such as toll road, sanitation, water supply, railway, air and land transportation, and marine transit (Latief, 2017). Those government efforts mentioned above were not successful yet. From 2005 until 2015, the success rate was only $2 \%$ for infrastructure projects that managed to do financial close and started the construction stage. The success rate, counted from two out of the 91 projects, was offered in 2005 at the Indonesia Infrastructure Summit 2005 until 2015 (The Committee for Acceleration of Priority Infrastructure Delivery, 2016). The low success rate of PPP implementation in Indonesia has encouraged the government to reformulate its strategy to optimize PPP project provision and development performance.

In 2005, the government again amended Presidential Regulation No.13/2010 and established Presidential Regulation No. 38/2015 on PPP in Provision of Infrastructure. Moreover, the government also issued Presidential Regulation No. 3/2016 on Accelerated Implementation of National Strategic Projects. National Strategic Projects/Proyek Strategis Nasional (PSN) were carried out by the government or business entities at both central and regional government levels that were strategic to increase growth and equalize development by increasing community welfare and regional development. There were 226 projects declared as PSN in Presidential Regulation No. 3/2016 consisting of 24 project sectors.

Drinking water supply is one of the sectors that has been using the PPP scheme in Indonesia. The drinking water supply sector is also classified as both priority and strategic projects since the enactment of Presidential Regulation No.3/2016. Also, according to the 2015-2019 National MidTerm Development Plan (RPJMN) 2015-2019, the government has targeted to reach $100 \%$ fulfillment of drinking water supply for all Indonesian people (Bappenas, 2014, p. 156). To achieve this strategic objective, the government directed its efforts to build drinking water supply basic infrastructure.

According to Presidential Presidential Regulation No.3/2016 on Accelerated Implementation of National Strategic Projects (which was then amended twice subsequently by Presidential Regulation No.58/2017 and No.56/2018), there are seven drinking water supply projects classified as national strategic projects. Those projects are West Semarang Drinking Water Supply; Umbulan Drinking Water Supply; Bandar Lampung Drinking Water Supply; Mamisata Drinking Water Supply; Jatiluhur Drinking Water Supply; Maminasata Drinking Water Supply; and Wasusokas Drinking Water Supply. At the latter stage, the national government selected the three highest priority projects in the drinking water supply sector to adopt the PPP scheme, namely: Bandar Lampung Drinking Water Supply, Jatiluhur Drinking Water Supply, and West Semarang Drinking Water Supply.

Bandar Lampung Drinking Water Supply has started using the PPP scheme since 2012. However, there was a delay during the tendering process. Bandar Lampung Drinking Water Supply has finally reached the Request for Proposal stage in August 2017 and obtained a signed agreement 
by March 2018, two years longer than the predetermined target. In brief, Bandar Lampung tendering process took six years long started from pre-qualification until financial close. The second priority project that used the PPP scheme is Jatiluhur Drinking Supply Water. In 2014, Minister of Public Works Djoko Kirmanto appointed the CEO of Perum Jasa Tirta II as a Government Contracting Agency(GCA)/Penanggung Jawab Proyek Kerjasama (PJPK) of Jatiluhur Drinking Water Supply Project. After three years of stagnant period, the Jatiluhur Water project was finally able to finish their Final Business Case (FBC) in 2017 and prepared for the Request for Proposal (RfP) stage in November 2019 (National Agency For Water Supply System Improvement, 2019). To sum up, from finishing their FBC until RfP preparation, it requires five years from 2014 until 2019.

The third priority project is theWestSemarang Water Supply project. According to National Agency For Water Supply System Improvement/Badan Peningkatan Penyelenggaraan Sistem Penyediaan Air Minum (BPPSPAM), West Semarang Drinking Water Supply has successfully finished their FBC preparation in November 2017 (National Agency For Water Supply System Improvement, 2017). PDAM Tirta Moedal as GCA and PT Sarana Infrastruktur was appointed by the Minister of Finance to prepare the FBC document. In January 2019, West Semarang Drinking Water Supply held the pre-qualification stage. Four consortiums passed the pre-qualification stage (Directorate General Budget Financing and Risk Management, 2019). The bid awarding announcement was held in September 2018. The winning bidder is PT Aetra Air Jakarta - PT Medco Gas Indonesia consortium (The Committee for Acceleration of Priority Infrastructure Delivery, 2018). Finally, West Semarang Drinking Water Supply reached a financial close in May 2019 (Ministry of Public Works and Housing, 2019). This project has successfully gone through the all processes within just two years.
West Semarang Drinking Water Supply is the fastest PPP water supply priority project than any other existing water supply project in Indonesia. Considering those factors mentioned above, West Semarang Drinking Water Supply becomes an interesting case to be learned to improve our understanding of successful drinking water supply PPP implementation in Indonesia. This research investigates the following research questions: What are the critical success factors for the PPP Project implementation in West Semarang Drinking Water?

\section{Literature Review \\ Public Private Partnership: Definition \& Concession}

Public Private Partnership (PPP) is an agreement between the government and the private sector, which partially or generally performs public services carried out by the private sector (Savas, 2000, p. 3). Furthermore, according to the Asian Development Bank, PPP is a long-term and contractual collaboration between public and private agencies to plan, finance, implement, and operate public services (Asian Development Bank, 2008, p. 1). Moreover, according to the Ministry of Finance, Singapore, in the PPP Handbook 2nd Version (2012), PPP is a procurement model that encourages the private sector's involvement in providing public services that were initially only carried out by public agencies. The private sector can be involved in many things, such as labor contracts, outsourcing services, or Business Process Outsourcing. Based on these definitions mentioned earlier, in brief, PPP is a contractual agreement between the government and the private sector to provide public services by planning, financing, implementing, and managing existing physical assets within a particular time, usually 20-30 years or more.

A concession agreement provides a longterm right to a particular private company or consortium to utilize all relevant assets 
within a government's jurisdiction, including the responsibility for operating the infrastructure's relevant assets and carrying on the existing assets' investment activities (World Bank, 2019). Once the agreement terminates, the private partners will return all of the asset ownership to the government. In the case of West Semarang waterdrinking project, the so-called Build-OperateTransfer (BOT) contract model is implemented.

BOT is a cooperation between government and private entities to provide public infrastructure products and services (Yang, Nisar, \& Prabhakar, 2009). This type of agreement is commonly used to develop greenfield (entirely new) projects, where the private entities bear the overall costs for infrastructure development during the contract period. In return, the private consortium gains its revenue from the fees paid by the citizens who enjoy the services or could also be covered by the government for particular sectors. The winning bidder forms a Special Purpose Vehicle (SPV) to finance, design, construct, and commercially operate the project within this model. After the project period ends, the SPV will transfer its project to the government (World Bank, 2019).

According to the APMG PPP Certification Guide issued by the World Bank (2016), PPP comprises of four main general stages: Firstly, planning and candidate identification (this stage aims to select the most appropriate project); Secondly, preparation (the preparation stage aims to assess PPP project feasibility to reduce the risk of project failure during the bidding process or during the project contract period); Thirdly, implementation and procurement (this stage aims to determine and develop a PPP contract that best fits the specific features of a project contract, so as to protect, and where possible, optimize value for money); and finally, contract management (aims to manage the process for selecting the best value proposals in a competitive and regulated environment, and executing contracts with the most suitable and reliable bidder).

\section{PPP Critical Success Factors (CSF) in Drinking Water Supply Project}

A previous study conducted by Ameyaw and Chan (2016) offers a valuable theoretical framework to examine the responsible factors behind a successful water supply project. They identified five critical success factors (CSF): Commitment of Partners; Strength of Consortium; Asset Quality; Political Environment; and National PPP Unit.

The first factor, Commitment of Partners. This key CSF formed by four indicators: Firstly, Strong and Competent Project Partner. The project partners stakeholder should maintain a total commitment throughout all the PPP stages, including adequate allocation of financial resources and human resources. Secondly, Strong and Competent Public Partner. On the other hand, the public partner should ideally possess sufficient experience and competence to manage the PPP Stage. Moreover, the public partner should facilitate capacity-building programs to increase public sector knowledge and skill about PPP projects. Also, the Public Partner has to hire professional advisors (technical, financial, legal, and environmental aspects) to help the public sector managing PPP projects. Thirdly, Internal Coordination within Government. Drinking-Water Supply Projects involve multiple stakeholders. The stakeholders need to arrange routine coordination meetings to resolve issues and challenges. Moreover, the stakeholders need a strong leading sector to coordinate these ministries. The fourth is Flexible Contract with Fair Risk Allocation. Welldefined and fair risk allocation is an essential part of PPP contracts to improving efficiency.

The second dimension, Strength of Consortium, comprises three indicators: Strong and Competent Private Partner serves as the first indicator. The private partner has to be chosen based on experience and expertise. A project is at a high risk of failure if the bidding criteria are solely based on the lowest fee and tariff. In addition to that, it remains crucial to 
take into consideration the second indicator: Effective Regulatory and Legal Structure. The existence of a well-established legal and regulatory framework will raise public benefits by assuring that the contract operates efficiently and provides sufficient protection to the private partner. Last but not least, Profitable Drinking Water Supply Project. It is a precondition for a drinking water supply to be successfully carried out as a PPP project. The project has to be driven by profit incentives by the private sector.

The third dimension covers the Asset Quality aspect. It consists of two CSF: Firstly, Quality Water Asset and Work Force, which is vital for brownfield (existing utilities), where private partners take over state-owned and operated drinking water supply systems. This method is known as Transfer-Operate-Transfer (TOT) PPP scheme. Secondly, Adequate Financing. The private partner project has to provide longterm capital as indicated by its ability to do financial close on time to start the project.

The fourth dimension, Political Environment Dimension, constitutes three indicators: Firstly, Capacity Building for Existing Staff. It is essential to do for PPP projects that use the TOT method. Secondly, Competitive Tendering. Participation of several strong bidders may offer extra bargaining powers to the awarding committee while providing the opportunity to choose the most experienced and competent consortium with a proven track record in managing another PPP projects in a similar sector. Finally, Government Commitment. A committed government is undoubtedly required to guarantee against some specific risks.

The final dimension, a National PPP Unit, is needed to coordinate and oversee all PPP activities, link foreign investors with local governments, sort out conflicts, promote accountability, and advocate legislative changes. PPP units can conduct four essential functions: Project support, framework development, knowledge management, and policy function.

\section{Methods}

This research combines a descriptive method with a qualitative approach to examine the responsible key success factors that have made the Semarang Water Supply Project outperform other similar PPP projects in the field. According to Hamdi \& Bahruddin (2014), descriptive research aims to examine a specific issue in society by exploring relevant activities, possible causal processes, and the influence of various phenomena in its surroundings. This approach is considered suitable for the Water Supply PPP Project case with its multidimensional nature.

Phone call interviews with seven selected national and local informants were conducted between April and June 2020 to collect the primary data. The selected informants represent the key responsible stakeholders at all three main stages of PPP, namely planning, preparation, and transaction stages, and accommodate triangulation of the perspectives of three relevantstakeholders: Central government agencies (BAPPENAS/ Ministry of National Development Planning, KPPIP/ National Committee for the Acceleration of Priority Infrastructure Delivery, Coordinating Ministry for Economic Affairs, Ministry of Finance and Ministry of Public Works \& Housing), private actor (the winning bid consortium), and the local state-owned enterprise (PDAM Tirta Moedal). The researchers identified the key actors for each stage in the West Semarang Water Supply PPP Project based on a careful examination of the relevant regulations and guideline, including the PPP Book 2018 issued by BAPPENAS/Ministry of National Development Planning, Minister of Finance Regulation No. 73/2018, and Minister of Public Works \& Housing No. 21/2018. Moreover, secondary data were obtained from national and local government agencies' annual and performance reports, and professional organizations, such as Indonesia Infrastructure Finance.

Finally, the ideal-type data analysis technique was employed to analyze the collected 
data. The ideal type is a qualitative data analysis strategy that involves making comparisons between theory and reality (Neuman, 2014, p. 487). The data obtained from the interviews were transcribed verbatim before categorizing into 11 critical success factors of PPP Project in Water Supply, as suggested by Ameyaw and Chan (2016). The three-column analysis was used to systematically analyze the data (from raw data, preliminary codes, to final code), as suggested by Saldaña (2021), and thus facilitating a streamlined codes-to-theory model for qualitative investigation.

\section{Results and Discussion Commitment of Partners}

Four indicators form the Commitment of Partners Dimension: Strong and Competent Project Partner; Strong and Competent Public Partner; Internal Coordination within Government; and Flexible Contract with Fair Risk Allocation. According to Ameyaw and Chan (2016), project partners and Government Contracting Agency (GCA) should be committed to allocating their best financial resources and human resources throughout all the PPP stages.

Based on our analysis, in the context of West Semarang, the commitment shown by the Mayor remains the most fundamental asset for a successful PPP. According to Regulation of the Minister of PUPR Number 19/2016 concerning Provision of Support from the Central Government and Local Governments in the Cooperation for the Implementation of the Drinking Water Supply System, Local Government has to assign BUMD to become a GCA to perform the project under PPP Scheme. The Mayor of Semarang City fulfilled this requirement by appointing the CEO of PDAM Tirta Moedal Semarang through Assignment Letter of Semarang City Mayor No.539/89 of 2016.

Moreover, the Mayor also proved his commitment by providing financial support for land acquisition worth Rp. 100 Billion plus another
Rp 150 Billion for the construction of secondary and tertiary network installations. Moreover, the Mayor of Semarang also ensures a fair and competitive price for water supply services by imposing Local Government Regulation of Semarang City No.8 of 2018. Many other local government heads do not introduce such regulation in their respective regions, which may harm either the water supply agency (due to underpriced) or service recipients (due to overpriced).

BPPSPAM classifies PDAM into three categories based on their individual performances, ranging from Healthy PDAM; Less Healthy PDAM; to Sick PDAM (BPPSPAM, 2017, hal. 2). A PDAM as a GCA should be classified as a healthy PDAM to perform a project under the PPP scheme. Four financial indicators indicate a healthy PDAM: Full Cost Recovery (FCR) Tariff establishment to assess PDAM's ability as GCA to buys bulk water, and assures it will not endanger the financial condition; Average Tariff. The minimum average tariff is Rp.3.000; Non-Revenue Water (NRW) has to be below $40 \%$ to minimize the system's risk, and Bankability to assesses PDAM's ability as GCA to makes Return of Investment (RoI). If a PDAM has a high debt level, it will affect the RoI. In measuring Bankability, it could be measured by the Debt Equity Ratio (DER) owned by PDAM. The maximum DER used in Drinking Water Supply projects is 30:70 or 0.433 (Ministry of Public Works and Housing, 2017, p. 18). In 2018, PDAM Tirta Moedal has a Healthy PDAM Category with a performance value of 3.57 (out of 5.00 Scale). The following is a table of PDAM Tirta Moedal Financial Capacity:

Based on the indicators and data shown above, PDAM Tirta Moedal as a GCA is classified as a healthy PDAM. As shown above, PDAM Tirta Moedal accommodates the FCR Tariff criteria; the average tariff is Rp. $3.870 / \mathrm{m}^{3}$, the NRW level is $38.73 \%$, and the DER is 0,111 . Moreover, PDAM Tirta Moedal as a GCA committed their financial support to build shared distribution network installation, with Rp.297 Billion amount. 
Table 1.

PDAM Tirta Moedal Financial Capacity Annual Year 2018

\begin{tabular}{cll}
\hline No. & \multicolumn{1}{c}{ Indicators } & \multicolumn{1}{c}{ Score } \\
\hline 1 & FCR Tariff based on NRW Riil (\%) & $106,14 \%$ \\
2 & Average Tariff $\left(\mathrm{Rp} / \mathrm{m}^{3}\right)$ & 3.870 \\
3 & Non Revenue Water (\%) & $38,73 \%$ \\
4 & Total Fixed Asset (Rp.000) & 219.402 .919 \\
5 & Total Asset (Rp.000) & 364.229 .032 \\
6 & Current Liabilities (Rp.000) & 33.477 .167 \\
7 & Long Term Debt (Rp.000) & - \\
8 & Total Equity (Rp.000) & 301.015 .970 \\
\hline
\end{tabular}

Sources: Obtained from PDAM Performance Book 2018, BPPSPAM (2018)

PDAM Tirta Moedal has shown its human resources-related commitment as indicated from the PPP Implementation Team and PPP Procurement Team composition, which consists of experienced and competent officers. The CEO of PDAM Tirta Moedal forms West Semarang Drinking Water Supply PPP Implementation Team through PDAM Tirta Moedal CEO Decree No. $690.05 / 107 /$ of 2017 . The detailed team members are shown below.

Table 2.

West Semarang Drinking Water Supply PPP Implementation Team

\begin{tabular}{lll}
\hline & $\begin{array}{l}\text { Financial and Law } \\
\text { Aspects }\end{array}$ & Technical Aspect \\
\hline Supervisors & $\begin{array}{l}\text { Head of Financial } \\
\text { Division } \\
\text { Hembers } \\
\text { Sub of Accounting }\end{array}$ & $\begin{array}{l}\text { Head of Planning and } \\
\text { Evaluation Division } \\
\text { Head of Research } \\
\text { and Development } \\
\text { Division }\end{array}$ \\
& $\begin{array}{l}\text { Head of Secretarial } \\
\text { Sub Division }\end{array}$ & $\begin{array}{l}\text { Head of Equipment } \\
\text { and Maintenance } \\
\text { Division }\end{array}$ \\
& $\begin{array}{l}\text { Head of Household } \\
\text { and Administration } \\
\text { Sub Division } \\
\text { Head of Public }\end{array}$ & Control Division \\
Relation Sub & \\
Division & \\
\hline
\end{tabular}

Source: Obtained from through PDAM Tirta Moedal CEO Decree No. 690.05/107/ of 2017

The second success indicator is related to the existence of a Strong and Competent Public Partner. To become a competent partner, the government should, among others, facilitate capacity-building programs to increase public sector knowledge and skills about PPP projects, and to hire professional advisors. Chileshe and Kavishe (2020), based on their study examining selected Tanzanian PPP projects, also suggest that a capacity-building program is required to increase GCA individual skills and knowledge about PPP projects. Moreover, Meng and colleagues (2011) also emphasize the strategic role of relevant professionals, such as legal advisers, asset appraisal experts, and investment/ financing consultants, particularly to help the local governments with a very limited PPP former experience.

The capacity building program is given to PDAM Tirta Moedal as GCA was carried out by BPPSPAM during Outline Business Case document preparation as a part of the feasibility study. BPPSPAM carried out a capacity-building program to submit Project Development Fund (PDF) request to the Ministry of Finance. Aside from BPPSPAM, Ministry of Finance provides a capacitybuilding program to introduce Viability Gap Fund (VGF) principles. Furthermore, Ministry of Finance also assigned PT Sarana Multi Infrastructure (PT SMI) to implement the capacity building through Project Development Fund facility. The capacity building that PT SMI carried out was Financial Business Case (FBC) preparation, and transaction stage assistance. Moreover, the Ministry of Finance assigned PT Penjamin Infrastruktur Indonesia to provides knowledge and understanding of infrastructure guarantees. Finally, PT PDAM Tirta Moedal gains benefits from the central governments' capacity building. It helped them gain knowledge about PPP implementation as PPP is a new scheme/concept in Indonesia.

The Public Partners also hired a professional consultant to assist PDAM Tirta Moedal in implementing the Project under the PPP scheme. Three central government agencies recruit experienced consultants to carry out the West 
Semarang Drinking Water Supply Project. The first agency, BPPSPAM, recruited consultants during OBC preparation by reviewing the data from the pre-FS documents. The next central government agency is KPPIP, which recruited a consultant for updating Real Demand Supply data. The third agency is Ministry of Finance, which assigned PT Sarana Multi Infrastructure (PT SMI) as a consultant. Furthermore, PT SMI hired PT Indonesia Infrastructure Finance (PT IIF) as a financial consultant, PT SMEC Denka as a technical consultant, and Armand Yapsunto Muharamsyah and Partner (AYMP) Atelier of Law as a legal consultant. AYMP is one of the seven legal consultants selected to become the Infrastructure Project Consultant Panel, which KPPIP approved based on the Letter of Appointment Number PEN-05/D.VI.M.EKON/10/2018 about the Establishment of the List of Consultants Panel 2018. Panel Consultants are consultants chosen by KPPIP for PSN Projects that require consultancy services. The next consultant is PT IIF, a private national company established by the government of the Republic of Indonesia cq. Ministry of Finance of the Republic of Indonesia, along with World Bank, Asian Development Bank (ADB), and other multilateral institutions. IIF has experience in providing infrastructure financing and advisory services focused on infrastructure projects (Indonesia Infrastructure Finance, 2018). The third consultant is PT SMEC Denka, a technical consultant for West Semarang Drinking Water Supply Project. PT SMEC Denka is a project management consultancy company from Australia. PT SMEC Denka was chosen to be one of the Panel Consultants in the Technical field. In addition to being a technical consultant for the West Semarang SPAM Project, PT SMEC Denka provides technical consultancy services to several projects using PPP schemes, such as: the Jakarta LRT Project, the Palembang LRT Project, and the Cikopo-Palimanan Toll Road.
Internal Coordination Within Government is the next indicator. Drinking-Water Supply Projects involves multiple stakeholders. The stakeholders need to arrange routine coordination meetings to resolve issues and challenges. Moreover, the stakeholders also need a solid leading sector to lead the coordination among these ministries. Internal coordination within the government in West Semarang Drinking Water Supply Project is going well. The Coordinating Ministry for Economic plays its role as the Leading Sector because it is responsible for coordinating, synchronizing, and solving problems with de-bottlenecking PSN projects that can solve complex and multisectoral problems. Based on Presidential Regulation No.3/2016, article 32 states the Coordinating Ministry for Economy monitors and evaluates PSN at least twice a year. In fact, the Coordinating Ministry for Economy conducted routine coordination meetings three times a year. Apart from routine meeting, there is a de-bottlenecking coordination meeting to resolve challenges or problems. The less frequent debottlenecking coordination meetings were held indicates that a PPP Project is running smoothly The Coordinating Ministry for Economy rarely held de-bottlenecking coordination meetings for the West Semarang Drinking Water Supply Project. PDAM Tirta Moedal as GCA also held a coordination meeting facilitated by PT SMI and the Ministry of Finance as the PDF facility provider, to discuss things related to the preparation stage and transaction stage. In addition, the Ministry of PUPR also held an internal coordination meeting at the beginning of the planning stage to discuss the funding scheme to be used by the West Semarang Drinking Water Supply, until finally it was decided to be funded by the PPP Scheme. The strong leadership played by the Coordinating Ministry for Economic to de-bottlenecking multisectoral coordination across responsible units, ministries, and agencies is also consistent with the suggestion 
provided by Meng and colleagues (2011) to ensure an effective and efficient PPP implementation.

In general, the main challenge for the West Semarang Drinking Water Supply Project challenge was not in implementing but more technical. However, most of the challenges have been tackled successfully. The project enjoys the Regional Head's commitment, a competent PPP Team, and good internal coordination within the government. The first challenge for West Semarang Drinking Water Supply Project was related to the land acquisition issue. This issue arose because the citizens disagreed with the procurement team's land acquisition offering price. This challenge was resolved by PDAM Tirta Moedal with consignment resettlement by entrusting the estimated compensation fees through Semarang District Court. Another challenge was related to the installation of water supply networks under crossing the toll roads. As a solution, the Coordinating Ministry for the Economic organized a de-bottlenecking coordination meeting and invited the Directorate General of Highways of the Ministry of Public Works and Housing PDAM Tirta Moedal (as the PJPK) to discuss related to the challenge.

According to Ameyaw and Chan (2016), flexible contracts with a fair risk allocation can be measured by clearly defining the allocation of risk between the government and the private sector, to be carried out fairly based on their responsibilities. The risk allocation between PDAM Tirta Moedal as GCA and PT Aetra Air Indonesia - PT Medco Energi Indonesia as Special Purpose Vehicle (SPV) for the West Semarang Drinking Water Supply has been allocated fairly. The risk allocation is managed by the authorities representing each party between GCA and SPV. Both parties agreed to share the potential risks. The risks borne by PJPK are in the form of land acquisition risks and raw water risks. Then, the risks held by SPV are in the design risks, construction risks, and operational risks. Finally, the risk of a force majeure situation will be borne together.
Meng et al. (2011) also emphasize the importance of defining clear and fair responsibilities between the government and the private partner. Reeves and colleagues (2015), in particular, warn of the dangers of opportunistic behaviour from both private partners and the government before the final sign-off on the contract. On the one hand, the SPV may attempt to seek possibilities to get better terms over the period, while government actors may also consider changing the rules of the game for their own sake, including the possession of particular assets. Both opportunistic motives may lead to inefficiencies and implicate the overall PPP performance, i.e. a long-lasting tendering period (Reeves, et al, 2015).

Previous studies across regions have consistently supported the joint commitment of relevant state and non-state actors as one of the most critical PPP success factors, although they remain varied in the emphasis and types of commitment required. See, for instance, Dithebe et al. (2019) in the case of South Africa, Babatunde et al. (2012) in the case of Nigeria, Ismail (2013) in the case of Malaysia, and Zou et al. (2020) in the case of Hongkong.

\section{Strength of Consortium}

According to Ameyaw and Chan (2016), the private partner has to be chosen based on experience and expertise. In the case of West Semarang, PT Aetra Air Indonesia - PT Medco Energi Indonesia as SPV is considered a competent project partner. PT Aetra Air Jakarta's experience is operating 10,500 liters/second of Water Treatment Plant (WTP) serving in North Jakarta, Central Jakarta, and East Jakarta. Ideally, a promising private partner should possess relevant former experience building and operating a minimum of 500 liters/second (WTP), as suggested by our informant from the Ministry of Finance. Therefore, in this case, the selected consortium does fulfill the competent criteria. In 
addition, PT Medco Energi Indonesia in operating SPAM, namely by becoming SPV for the Umbulan Drinking Water Supply Project by utilizing the WTP of 4,000 liters/second (Medco Energi, 2016). Furthermore, the President Director of PT Aetra Air Jakarta, Mohammad Selim, has adequate experience in leading a drinking water company since 2011. The collective expertise of PT Aetra Air Jakarta - PT Medco Energi Indonesia as GCA has contributed to accelerating the construction progress beyond the predetermined target. Up to July 7, 2020, it has reached $42 \%$, while the actual construction target was only $22 \%$. The West Semarang SPAM project can still build construction on time, amidst the Covid-19 pandemic.

Effective Regulatory and Legal Structure is the subsequent indicator of the strength of consortium. A well-established legal and regulatory framework will raise public benefits by assuring that the contract operates efficiently and provides sufficient protection to the private partner. The regulations that form the legal basis for implementing the West Semarang SPAM Project using the PPP Scheme are: Government Regulation Number 122 of 2015 concerning Drinking Water Supply System; Presidential Regulation No38/2015 on Government Cooperation with Business Entities in Infrastructure Provision; Regulation of the Minister of PPN / Head of Bappenas No4/2015 concerning Procedures for Implementation PPP for Provision of Infrastructure; Regulation of the Minister of PUPR Number 19 of 2016 concerning Provision of Support from the Central Government and/ or Regional Governments in Cooperation in the Implementation of the Drinking Water Supply System; and PMK Number 73 of 2018 concerning Facilities for the Preparation and Implementation of Cooperation Project Transactions between the Government and Business Entities in the Provision of Infrastructure.

A profitable drinking water supply project is another precondition for a successful drinking water supply PPP project. From the private sector's perspective, the motive of profit incentives should ideally drive the PPP project. According to the Asian Development Bank (2002), the following aspects can be employed to examine whether a particular project is profitable or not: Project Cost; Water Tariff; Production Capacity; Financial Internal Rate of Return (FIRR); and Net Present Value. A water supply PPP project is considered profitable if it has a project cost of Rp. 1 trillion, a minimum tariff of Rp. 3000, a production capacity of 1000 liters/second, and the minimum FIRR value is $12 \%$. West Semarang Drinking Water Project is Rp. 1,204,615,000,000; the Tariff applies when it will start the operation is Rp. 5.841; 1,000 liters/second WTP capacity; and the FIRR value is $16 \%$. Based on the data above, the West Semarang Drinking Water Supply is profitable because it has met all of the required indicators

A well-established legal and regulatory framework will raise public benefits by assuring that the contract operates efficiently and provides sufficient protection to the private partner. This argument is consistent with Babatunde et al. (2012) standpoint to develop an effective policy and laws as the basis for the PPP contractual arrangements. Moreover, a profitable drinking water supply project is another precondition for a successful drinking water supply PPP project. A potentially profitable project is a must for attracting domestic and foreign investors. (Meng et al., 2011) From the private sector's perspective, the motive of profit incentives should ideally drive the PPP project. According to World Bank (2002) measurement, West Semarang Drinking Water Supply is profitable because it has met all of the required indicators.

\section{Asset Quality}

According to Ameyaw and Chan (2016), Asset Quality has two indicators: Quality Water Asset \& Work Force and Adequate Financing. But for Semarang Barang, Drinking Water Supply 
could just be measured by adequate financing because West Semarang Drinking Water Supply Project is using Build-Operate-Transfer (BOT). The private partner project has to provide longterm capital. It could be shown through private partner ability to do financial close on time to start the project. Based on Regulation of the Minister of PPN / Head of Bappenas No4/2015 on Procedures for Implementation PPP for Provision of Infrastructure, private partner as SPV has to do financial close 12 months after agreement signing. PT Aetra Air Jakarta - PT Medco Energi as West West Semarang Drinking Water Supply SPV has reached financial closing with an investment of around RP.458 billion to build WTP, reservoirs, and transmission networks in May 2019. The SPV has reached financial closing six months after agreement signing. They signed the PPP agreement in October 2018. Hence, PT Aetra Air Jakarta - PT Medco Energi has adequate financing because they can be reached financial faster than the due according to Regulation of the Minister of PPN / Head of Bappenas No. 4/2015 Procedures for Implementation PPP for Provision of Infrastructure. Rouse (2014) argues that SPV's ability to arrange a long-term innovative and flexible capital (financial package) is key to determining the consortium's chances of winning the project. Furthermore, Hussain \& Siemiatycki (2018) suggest that SPV has to achieve positive value for money in the PPP project.

\section{Political Environment}

Theoretically, the political environment should cover three indicators: capacity building for existing staff, competitive tendering, and government commitment. However, in West Semarang's case, the researchers excluded the capacity building for existing staff, mainly because it is a PPP-BOT project.

Competitive Tendering as the first indicator offers more bargaining powers to the awarding committee while providing an opportunity to choose the most experienced and competent consortium with a proven track record in managing other PPP projects in a similar sector. The transaction or tendering stage started with the prequalification phase. At the pre-qualification stage, ten consortiums submitted PQ documents. These ten consortiums are: Suez Limited Consortium - PT Brantas Abipraya Persero - PT Elnusa Tbk; PT Memiotec Indonesia - PT China Singapore Indonesia Water Company; PT Aetra Air Jakarta - PT Medco Gas Indonesia; PT Bangun Cipta Kontraktor - PT Wijaya Karya (Persero) - PT Bangun Tjipta Sarana; Manila Water Inc - PT Sarana Tirta Ungaran - PT Adaro Tirta Mandiri; PT PP (Persero) - Cobra Intalaciones Y Servicios; PT PAM Lyonnaise Jaya - PT Bahtera Hijau Mandiri; PT Nouval Perkasa - PT China Construction Yangtze River Indonesia; PT Metito Indonesia - PT Indah Karya; and Penyao Environmental Protection Co Ltd (PDAM Tirta Moedal, 2019).

The Awarding Committee announced four consortiums that passed the pre-qualification in March 2018: 1) PT Aetra Air Jakarta - PT Medco Gas Indonesia, 2) PT PP (Persero) - Cobra Intalaciones Y Servicios, 3) Manila Water Inc - PT Sarana Tirta Ungaran - PT Adaro Tirta Mandiri, and 4) Suez Limited Consortium - PT Brantas Abipraya Persero - PT Elnusa Tbk. All of these consortiums passed the PQ stage and were entitled to submit RFP documents. Finally, in August 2018, the bid awarding was announced to PT Aetra Air Jakarta - PT Medco Gas Indonesia.

The next indicator, according to Ameyaw and Chan (2016), is Government Commitment. A committed government is required to guarantee the project against some specific risks. According to Regulation of the Minister of PPN / Head of Bappenas No4/2015 on Procedures for Implementation PPP for Provision of Infrastructure, both central and local government are responsible for providing the required government supports.

On behalf of the central government, the Ministry of Finance was ready to support the West 
Semarang Project with Viability Gap Fund (VGF), a grant to build part of the project infrastructure worth Rp.87 Billion. Although the SPV did not take the offer (because they consider themselves financially adequate), this fact confirms the central government's tangible support. On top of that, The Ministry of Finance has assigned several StateOwned Enterprises under the Ministry of Finance, which are: PT Penjaminan Infrastruktur Indonesia to guarantees the infrastructure project; PT Sarana Multi Infrastruktur to implement Project Development Fund (PDF) support, whose scope includes project preparation and transaction stage assistance; and Ministry of Public Works and Housing. The Ministry of Public Works and Housing provides the construction of the Main Distribution Network/Jaringan Distribusi Utama (JDU) through the State Budget worth RP.221 billion. Apart from that, The Ministry of Public Works and Housing provides the construction of a Water Treatment Plant in Jatibarang Reservoir worth Rp. 105 Billion.

On the other hand, the Semarang City Government supports the West Semarang Drinking Water Supply Project by issuing a crucial local government regulation. It is also important to note that the Semarang Regional House of People's Representatives was also supporting the Mayor's initiative to ratify the Local Government Regulation No.8/2018 on PPP Implementation of the West Semarang Drinking Water Supply System. Moreover, Semarang City Government allocated considerable fiscal support worth Rp. 150 Billion through PDAM Tirta Moedal to construct the Secondary Network and the Tertiary Network. They also provided financial support for land acquisition worth Rp. 100 Billion.

Semarang Regional House of People's Representatives also provided their support by establishing Special Committees for West Semarang Drinking Water Supply Project. The Special Committees is chaired by Joko Susilo, who is the Secretary of B Comission.
Their responsibility is Ratifying Semarang City Local Government Regulation on Public Private Partnership Implementation of the West Semarang Drinking Water Supply System. In addition, The Special Committees have to monitor the projects. Furthermore, Semarang Regional House of People's Representatives and Semarang City Mayor signed a Memorandum of Understanding between the Semarang City Government and Semarang Regional House of People's Representatives on Temporary Budget Priorities and Ceilings for the Revised Regional Revenue and Expenditure Budget for the 2016 Fiscal Year. Initially, there was no budget for West West Semarang Drinking Water Supply Project and acquisition. In the Temporary Budget Priority and Ceiling of the Semarang Regional House of People's Representatives, the Mayor of Semarang City agreed to budget Rp. 100 billion for the land acquisition (Semarang Regional House of People's Representatives , 2016, pp. IV-93).

In West Semarang Drinking Water Supply Project, a political environment is shown as a critical success factor. A competitive tendering as the first indicator offers more bargaining powers to the awarding committee while providing an opportunity to choose the most experienced and competent candidates. This indicator has been commonly used within the context of concessionaire selection in China's PPP projects under BOT model (Meng et al., 2011). If the tendering process can only attract a minimum number of interested candidates, it is nearly impossible for the GCA to choose a competent and experienced consortium. Moreover, Meng and colleagues also argue that the bidding award through tendering competition, at the same time, also increases the government's bargaining power in relation to the investor pursuing the PPP project.

A committed government is required to guarantee the project against some specific risks. Both central and local governments are 
responsible for providing the required supports for the West Semarang Project. Babatunde et al. (2012) argue that government guarantee comprises government involvement by providing a guarantee, multi-benefits objectives, and political support. In addition, Osei-Kyei \& Chan (2017) also emphasizes the support provided by the parliament to provide the necessary assistance for the private partner. It is also interesting to look at the work of Verhoest and colleagues (2015) on the development of a 'PPP Governmental Support Index' (GSI) to measure the level of support provided by the national government, particularly in setting up a conducive institutional framework for PPP implementation.

\section{National PPP Unit}

According to Ameyaw and Chan (2016), the National PPP Unit is needed to coordinate and oversee all PPP activities, link foreign investors with local governments, sort out conflicts, promote accountability, and advocate legislative changes. PPP units can conduct four key functions: project support, framework development, knowledge management, and policy function. Indonesia has a National PPP Unit called the Indonesia PPP Joint Office. The members of the Indonesia PPP Joint Office consist of: Ministry of National Development Planning (BAPPENAS), Coordinating Ministry for Economic Affairs, Ministry of Finance, Ministry of Home Affairs, Investment Coordinating Board (BKPM); the National Public Procurement Agency (LKPP); PT Sarana Multi Infrastruktur (PT SMI); and PT Penjaminan Infrastruktur Indonesia (PT PII). Indonesia PPP Joint Office has the following functions: 1) To manage coordination between Ministries/Agencies/Local Governments, with GCA and SPV regarding of PPP Projects; 2) To facilitate all the stakeholders regarding the implementation of Projects under PPP Schemes in Indonesia; and 3) Provide capacity building programs on the PPP Scheme implementation.
West Semarang Drinking Water Supply has enjoyed all of these three services provided by the Indonesia PPP Joint Office. It is evident from the existence of routine coordination meetings held by the Coordinating Ministry for the Economic as the de-bottlenecking agent by inviting PDAM Tirta Moedal as GCA and the other Stakeholders, such as Ministry of Finance and Ministry of Public Works and Housing. Indonesia PPP Joint Ofice also facilitates all parties involved in the implementation of the West Semarang SPAM Project. Finally, the Joint Office members also support the capacitybuilding programs via its extended agent, PT SMI (supervised by the Ministry of Finance), to facilitate Project Development Fund for the West Semarang Drinking Water Supply Project. Ministry of Finance also assigned PT PII to guarantee the infrastructure.

There is an abundance of existing works of literature emphasizing the strategic role of a dedicated national unit within the PPP context. Puentes (2020), for instance, argues that the existence of a national PPP unit remains pivotal to handling de-bottlenecking problems in the PPP process and delivering the necessary technical support for the stakeholders with limited capacity in dealing with the PPP projects.

Furthermore, Van den Hurk et al. (2016), based on their studies in nineteen European countries, classify the varieties of government supports provided through a dedicated national PPP unit under four categories: first, skeptical systems with little or zero institutional support from the PPP unit; second, previously existing but now unoccupied units; third, existing national PPP units with limited responsibilities; and fourth, significant national PPP units. In West Semarang, it is argued that the Indonesia PPP Joint Office belongs to the third category with a possibility to be further developed to the fourth category. Tserng and colleagues (2012) highlight the central role of a national PPP office to guarantee all relevant subordinate authorities' trust. 


\section{Conclusion}

This article contributes to theoretical and empirical literature as well as insights to PPP policy makers. The main objective was to identify the CSFs for successful drinking water supply projects operated under the PPP scheme. This issue remains underexplored, especially within the Indonesian context. Therefore, this article will be valuable for academicians, government officers, and professionals in the field.

Based on the analysis, in a nutshell, there are five critical success factors for the West Semarang Water Supply Project: 1) Strong commitment from Government Contracting Agency (GCA), Regional Head, and Central Government; 2) Competent and experienced project partners; 3) Long-term capital provided by the private partner; 4) Tangible political support from the central government, the Mayor, and the Regional House of Representatives; and 5) The existence of a particular Indonesia PPP Joint office that functions as a coordinator and facilitator among the stakeholders. The lessons from the West Semarang PPP Project's case can serve as an inspiration for other drinking water supply projects that also adopt the PPP Scheme to improve their performance. The lessons should not be seen as a one-size-fits-all approach due to individual PPP projects' characteristics but can be used as a point of reference to explore further solutions for general problems faced by a PPP project in water supply context.

Firstly, it is evident that tangible support from heads of local governments remains a necessary success factor for the project. The local leader's commitment can be delivered in the form of support to the GCA by issuing an official assignment letter to appoint the CEO of PDAM. In addition, the Regional Head's commitment can be demonstrated through the issuance of Regional Regulations as a legal basis and providing financial support for land acquisition.

Ideally, the GCA's PPP Implementation Team should also incorporate the structural leaders within the PDAM. This condition is very crucial to ensure the commitment and responsibility of the PPP Implementation Team as the basis to implement the PPP Scheme successfully. Also, the PPP Team must proactively coordinate with the Central Government, especially when there are obstacles that require the Central Government's resolution. The PPP Joint Office, facilitated by the Coordinating Ministry for the Economic, could play a pivotal role as the de-bottlenecking agent.

It is also important for the local governments to consider taking the consignment route by entrusting the estimated price of compensation through the court as a promising solution for addressing land acquisition problem. This issue is generally rooted in community resistance, who do not agree to the bid price. Finally, PDAM as a GCA of Drinking Water Supply Project must proactively propose government support to the central government to improve the SPAM project's feasibility, such as submitting PDF support to the Ministry of Finance.

\section{Acknowledgements}

We acknowledge funding supports provided by the Policy, Governance, and Administrative Reform Research Cluster at the Faculty of Administrative Science, Universitas Indonesia, for the main author under the Small Grant for Supporting Student Publication Program.

\section{References}

Adji, G. (2010). The Smart Handbook of Public Private Partnership: Konsep dan Praktik Meningkatkan Investasi di Sektor Infrastruktur. Jakarta: Rene Publisher.

Ameyaw, E. E., \& Chan, A. P. (2016). Critical Success Factors for Public Private Partnership in Water Supply Projects. Facilities. 34(4), 124-160. https://doi. org/0.1108/F-04-2014-0034

Asian Development Bank. (2002). Handbook for the Economic Analysis of Water Supply 
Projects. Manila: Economics and Economics and Development Resource Center.

Asian Development Bank. (2008). Public-Private Partnership (PPP) Handbook. Manila: Asian Development Bank.

Babatunde, S. O., Opawole, A., \& Akinsiku, 0. E. (2012). Critical success factors in public-private partnership (PPP) on infrastructure delivery in Nigeria. Journal Of Facilities Management. https://doi. org/10.1108/14725961211246018

Bappenas. (2014). Rencana Pembangunan Jangka Menengah Nasional 2015-2019: Buku I Agenda Pembangunan Nasional. Jakarta: Bappenas.

Carnis, L., \& Yuliawati, E. (2013). Nusantara: Between sky and earth could the PPP be the solution for. Case Studies on Transport Policies. World Conference on Transport Research Society. 1,18-26. https://doi. org/10.1016/j.cstp.2013.08.003

Cheung, E., Chan, A., \& Kajewski, S. (2009). Reasons for implementing public private partnership projects: Perspectives from Hongkong, Australian, and British Practicioner. Journal of Property Investment and Finance, 27(1), 81-95. https://doi.org/ 10.1108/14635780910926685

Chileshe, N., \& Kavishe, N. (2020). Capacity Building For Tanzanian Public private Partnerships (Ppps) Projects: Challenges And Advocated Solutions. Scott, L and Neilson, C J (Eds) Proceedings of the 36th Annual ARCOM Conf (pp. 186-195). UK: Association of Researchers in Construction Management.

Creswell, J. W. (2013). Research Design: Qualitative, Quantitative, and Mixed Method. California, US: SAGE Publication Inc.

Directorate General Budget Financing and Risk Management. (2019). Proyek KPBU SPAM West Semarang. Retrieved September 20, 2020, from KPBU - DJPPR: http://kpbu. djppr.kemenkeu.go.id/proyek/proyekkpbu-spam-semarang-barat/

Dithebe, K., Aigbavboa, C. O., Thwala, W. D., \& Oke, A. E. (2019). Factor analysis of critical success factors for water infrastructure projects delivered under public-private partnerships. Journal of Financial Management of Property and Construction. 24(3), 338-357 https://doi.org/10.1108/ JFMPC-06-2019-0049

Hamdi, A. S., \& Bahruddin. (2014). Metode Penelitian Kuantitatif: Aplikasi dalam Pendidikan. Yogyakarta: Deepublisher

Harun, R., \& Ardianto, E. (2011). Komunikasi Pembangunan dan Perubahan Sosial. Jakarta: Rajawali Pers.

Hussain, S., \& Siemiatycki, M. (2018). Rethinking the role of private capital in infrastructure PPPs: the experience of Ontario, Canada. Public Management Review, 20(8), 11221144. https://doi.org/10.1080/14719037 .2018 .1428412

Indonesia Infrastructure Finance. (2018). IIF Annual Report 2018. Jakarta: PT IIF

Latief, R. U. (2017). Risk Mitigation Strategy for Public Private Partnership (PPP) of Airport Infrastructure Development Projects in Indonesia. Proceedings of the International Multi Conference of Engineers and Computer Scientists 2017 Vol II, 1-6.

Maulana, R. (2019, March 20). Pemenang SPAM Jatiluhur Diumumkan Juni. September 30, 2019, Retrieved from Bisnis. com: https://ekonomi.bisnis.com/ $\mathrm{read} / 20190320 / 45 / 902275 /$ pemenangspam-jatiluhur-diumumkan-juni

Medco Energi. (2016, December 30). Penandatanganan Perjanjian Sindikasi Pembiayaan Proyek Sistem Penyediaan Air Minum Umbulan. Retrieved Juli 26, 2020, from Medco Energi - The Energy Company Of Choice: https://www.medcoenergi.com/ id/subpagelist/view/11/2478 
Meng, X., Zhao, Q., \& Shen, Q. (2011). Critical success factors for transfer-operate-transfer urban water supply projects in China. Journal of Management in Engineering, 27(4), 243-251. https://doi.org/10.1061/ (ASCE)ME.1943-5479.0000058

Ministry of Public Works and Housing. (2017). Modul Kelayakan Finansial. Bandung: Badan Pengembangan SDA, Kementerian PUPR.

Ministry of Public Works and Housing. (2019, May 27). Konstruksi SPAM West Semarang Ditargetkan Selesai dalam 1.5 Tahun. Retrieved April 16, 2020, from https://www. pu.go.id/berita/view/17020/konstruksispam-semarang-barat-ditargetkan-selesaidalam-1-5-tahun

National Agency For Water Supply System Improvement. (2017). Buku Kinerja PDAM 2017. Jakarta: BPPSPAM.

National Agency For Water Supply System Improvement. (2017, November). Penyelenggaraan SPAM Melalui KPBU / B to B. Retrieved September 23, 2020, from BPPSPAM: http://bppspam. com:8090/forum/assets/frond/upload/ Kerjasama\%20investasi $\% 20$ SPAM $\% 20$ melalui $\% 20$ KPBU $\% 20$ atau $\% 20$ B $\% 20$ to\%20B.pdf

National Agency For Water Supply System Improvement. (2019, September 17). Indonesia PPP Projects in Water Supply Sector. Retrieved September 24, 2020, from BPPSPAM: http://sim.ciptakarya. pu.go.id/bppspam/assets/assets/upload/ Indonesia__PPP_Projects_in__Water_ Supply_2019.pdf

Neuman, W. L. (2014). Research Methods: Qualitative and Quantitative Approaches. Essex: Pearson Education.

Osei-Kyei, R., \& Chan, A. P. (2017). Implementing public-private partnership (PPP) policy for public construction projects in Ghana: critical success factors and policy implications. International Journal of Construction Management, 17(2), 113-123. PDAM Tirta Moedal. (2019). Paparan SPAM West Semarang. Semarang, Jawa Tengah, Indonesia.

Puentes, R. (2020). Strengthen Federalism: Establish a National PPP Unit to Support Bottom-Up Infrastructure Investment. Retrieved March 19, 2021, from Brookings: https://www.brookings.edu/research/ strengthen-federalism-establish-anational-ppp-unit-to-support-bottom-upinfrastructure-investment/

Rakić, B., \& Rađenović, T. (2011). Public-Private Partnerships As An Instrument Of New Public Management. Facta Universitatis Series: Economics and Organization 8(2), 207-230.

Riyadi, \& Baratakusumah, D. S. (2005). Perencanaan Pembangunan Daerah. Jakarta: Gramedia Pustaka Utama.

Rouse, M. (2014), The worldwide urban water and wastewater infrastructure challenge, International Journal of Water Resources Development, 30(1), 20-27. https://doi.or g/10.1080/07900627.2014.882203

Saldaña,J.(2021). The coding manual for qualitative researchers. SAGE Publications Limited.

Savas, E. (2000). Privatization and Public Private Partnership. New York: Seven Bridges Press.

Semarang Regional House of People's Representatives. (2016). Prioritas dan Plafon Anggaran Sementara APBD Perubahan Tahun Anggaran 2016. Kota Semarang: DPRD Kota Semarang.

Susantono, B., \& Berawi, M. (2012). Perkembangan Kebijakan Pembiayaan Infrastruktur Transportasi Berbasis Kerjasama Pemerintah Swasta di Indonesia. Jurnal Transportasi 2 (6), 93-102.

The Committee for Acceleration of Priority Infrastructure Delivery. (2016, January 25). Framewrok Pembangunan Infrastruktur 
Indonesia. Retrieved October 7, 2019, from KPPIP: https://ekon.go.id/ekliping/ download/1952/1396/20160126-undippresentation-framework-pembangunaninfrastruktur-indonesia-final.pdf

The Committee for Acceleration of Priority Infrastructure Delivery. (2018, November 26). SPAM West Semarang Dikawal Hingga Mengalir. Retrieved June 20, 2020, from Komite Percepatan Penyediaan Infrastruktur Prioritas: https://kppip.go.id/berita/spamsemarang-barat-dikawal-hingga-mengalir/

The World Bank. (2004). Indonesia, Averting an Infrastructure Crisis: Framework for Policy and Action. Jakarta: The World Bank Office Jakarta.

The World Bank. (2016). The APMG Public Private Partnership Certification Guide. Washington, DC: World Bank Group.

Todaro, M., \& Smith, S. (2012). Economic Development (11th edition). New York: Pearson .

Tserng, H. P., Russell, J. S., Hsu, C. W., \& Lin, C. (2012). Analyzing the role of national PPP units in promoting PPPs: Using new institutional economics and a case study. Journal of construction engineering and management, 138(2), 242-249. https://doi.org/10.106 1/\%28ASCE\%29C0.1943-7862.0000398

Verhoest, K., Petersen, O. H., Scherrer, W., \& Soecipto, R. M. (2015). How do governments support the development of public private partnerships? Measuring and comparing PPP governmental support in 20 European countries. Transport Reviews, 35(2), 118139. https://doi.org/10.1080/01441647. 2014.993746

Walker, C., Mulcahy, J., Smith, A., Lam, P. T. I., \& Cochrane, R. (1995). Privatized Infrastructure. London: Thomas Telford.

Wibowo, A. (2006). Indonesia's Experience on Managing PPP Infrastructrure Projects. Jakarta: Secretariat of Agency for Research and Development.

World Bank (2019). Build-Operate-Transfer (BOT) and Design-Build-Operate (DBO) Projects. Retrieved March 18, 2019, from: World Bank https://ppp.worldbank.org/ public-private-partnership/agreements/ concessions-bots-dbos

Yang, J., Nisar, T. M., \& Prabhakar, G. P. (2009). Critical success factors for build-operatetransfer (BOT) projects in China. Irish Journal of Management, 36(3) 147-161. https://doi.org/10.1515/ijm-2017-0016

Zou, W., Kumaraswamy, M., Chung, J., \& Wong, J. (2014). Identifying the critical success factors for relationship management in PPP projects. International Journal of Project Management, 32(2), 265-274. https://doi. org/10.1016/j.ijproman.2013.05.004 